\title{
Induction of Progestin Receptors by Estradiol in the Forebrain of Estrogen Receptor- $\alpha$ Gene-Disrupted Mice
}

\author{
C. A. Moffatt, ${ }^{1}$ E. F. Rissman, ${ }^{2}$ M. A. Shupnik, ${ }^{3}$ and J. D. Blaustein ${ }^{1}$ \\ ${ }^{1}$ Neuroscience and Behavior Program and Center for Neuroendocrine Studies, University of Massachusetts, Amherst, \\ Massachusetts 01003, and Departments of ${ }^{2}$ Biology and 3/nternal Medicine, University of Virginia, Charlottesville, \\ Virginia 22903
}

Mice, rats, and humans have two types of estrogen receptors, estrogen receptor- $\alpha(\mathrm{ER} \alpha)$ and estrogen receptor- $\beta$ (ER $\beta)$. Estrogen receptor- $\alpha$ gene-disrupted (ER $\alpha$-disrupted) mice bear two nonfunctional copies of the $\mathrm{ER} \alpha$ gene. This mutation blocks the synthesis of full-length $\mathrm{ER} \alpha$, renders the animals infertile, and inhibits the induction of female sexual behaviors by estradiol and progesterone. It is likely that many of the processes contributing to the regulation of sexual receptivity by estradiol and progesterone are compromised in ER $\alpha$-disrupted mice. However, given the importance of progesterone in the regulation of sexual receptivity and given the importance of progestin receptors (PRs) in mediating the responses of females to progesterone, we investigated the effects of $\mathrm{ER} \alpha$ disruption on the induction of PRs by estradiol in the forebrain.

We hypothesized that estradiol would induce PRs in wildtype mice but not in ER $\alpha$-disrupted mice. Ovariectomized wild- type and ER $\alpha$-disrupted mice were implanted with either estradiol-filled capsules or empty capsules for $5 \mathrm{~d}$, after which their brains were processed for the immunocytochemical detection of PR. Estradiol increased the number of PRimmunoreactive cells in both wild-type and ER $\alpha$-disrupted mice. The residual responsiveness of $\mathrm{ER} \alpha$-disrupted mice to estradiol could be accounted for by an ER $\beta$-dependent mechanism or another as yet unidentified estrogen receptor; however, because $\mathrm{ER} \alpha$-immunoreactivity and PCR product representing the $3^{\prime}$ end of $\mathrm{ER} \alpha$ mRNA were found in at least one $\mathrm{PR}$-containing region of the $\mathrm{ER} \alpha$-disrupted mice, an $\mathrm{ER} \alpha$ splice variant may also mediate the induction of PR-immunoreactivity in $\mathrm{ER} \alpha$-disrupted mice.

Key words: estrogen receptors; progestin receptors; ventromedial hypothalamus; ovariectomy; estradiol; progesterone
Activation of hypothalamic progestin receptors (PRs), particularly PRs in the ventromedial hypothalamus (VMH), influences many neuroendocrine-controlled processes in female rats, including preovulatory surges in gonadotropin secretion and female sexual behaviors (Blaustein and Olster, 1989; Rubin and Barfield, 1983a,b; Kalra, 1993). Presumably, the initiation of these events is a consequence of activated progestin receptors binding to PR response elements and facilitating gene transcription, as well as protein synthesis (Blaustein and Olster, 1989; Pfaff et al., 1994). Blockade of PR activation, via the use of progesterone antagonists or antisense oligonucleotides to PR mRNA, disrupts PRmodulated processes and, as a consequence, disrupts the PRdependent facilitation of sexual behavior (Brown and Blaustein, 1984; Bittencourt et al., 1992; Mani et al., 1994; Ogawa et al., 1994; Lydon et al., 1995).

Although the activation of PRs contributes to the regulation of female sexual behaviors, treatment with progesterone by itself does not facilitate sexual receptivity. For progesterone to facilitate sexual behaviors, female rats must first be exposed to estradiol (Boling and Blandau, 1939). The reason for this may lie with

\footnotetext{
Received March 10, 1998; revised Aug. 18, 1998; accepted Sept. 3, 1998.

This research was supported by National Institutes of Health Grants HD08181 (C.A.M.), MH56187 (J.D.B.), K05-MH01312 (J.D.B.), NS35429 (E.F.R.), KO2-MH 01349 (E.F.R.), and HD25719 (M.A.S.). We thank Dr. Dennis Lubahn for providing EFR with the heterozygotic ER $\alpha$-disrupted mice used to set up our colony and for expert technical and scientific consultation. We also thank Robin Lempicki and Xia Li for their excellent technical assistance.

Correspondence should be addressed to C. A. Moffatt, Department of Biology, San Francisco State University, 1600 Holloway Avenue, San Francisco, CA 94132. Copyright (C) 1998 Society for Neuroscience $\quad 0270-6474 / 98 / 189556-08 \$ 05.00 / 0$
}

the manner in which PRs are regulated in the areas of the brain that control female sexual behaviors. Neural PRs can be divided into two populations: a population whose synthesis is induced by estradiol and a population whose synthesis is not (MacLusky and McEwen, 1978). It is the former population, the estradiol-induced PRs, that is believed to be involved in the regulation of female sexual receptivity (Blaustein and Feder, 1979). When the concentration of estradiol-induced hypothalamic PRs is high, females exhibit sexual behavior in response to treatment with progesterone (Blaustein and Olster, 1989; Pfaff et al., 1994). Conversely, when the concentration of estradiol-induced PRs is low, typical doses of progesterone do not facilitate sexual behaviors (Blaustein and Feder, 1980; Blaustein and Olster, 1989).

Recently, a strain of mice has been developed that lacks functional copies of the estrogen receptor- $\alpha(\mathrm{ER} \alpha)$ form of the estrogen receptor (Lubahn et al., 1993; Couse et al., 1995). Female $\operatorname{ER} \alpha$ gene-disrupted (ER $\alpha$-disrupted) mice show a variety of reproductive deficits, including a lack of sexual behavior (Ogawa et al., 1996), even after hormone treatments that are sufficient to induce sexual behavior in wild-type (WT) mice of the same strain (Rissman et al., 1997). It is unlikely that the lack of behavioral responsiveness to estradiol and progesterone can be attributed to the disruption of a single ER $\alpha$-regulated process. Instead, the impairment in behavior is more likely to be the product of a constellation of neuroendocrine disruptions. With this caveat in mind, we investigated whether $\operatorname{ER} \alpha$-disrupted mice showed impairments in one component of the mechanism that regulates sexual behavior in female mice, the induction of hypothalamic PRs in response to treatment with estradiol. In 

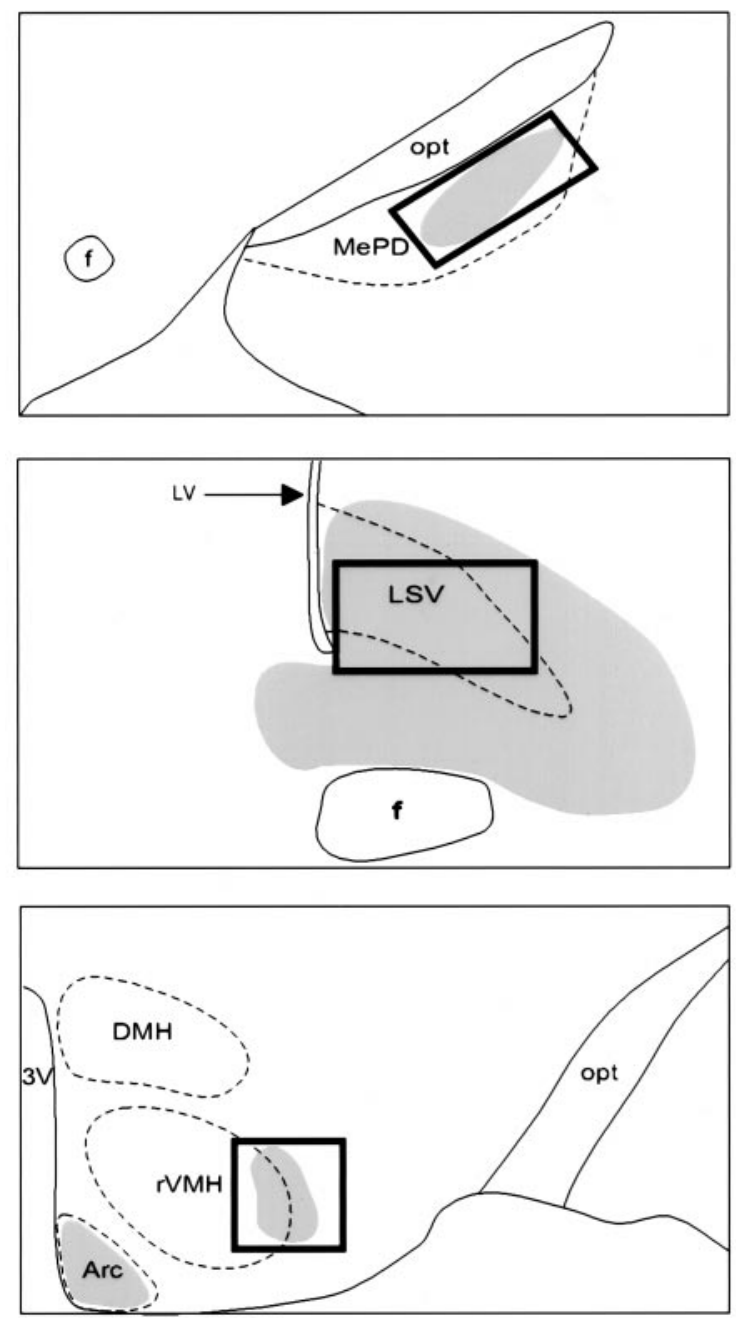
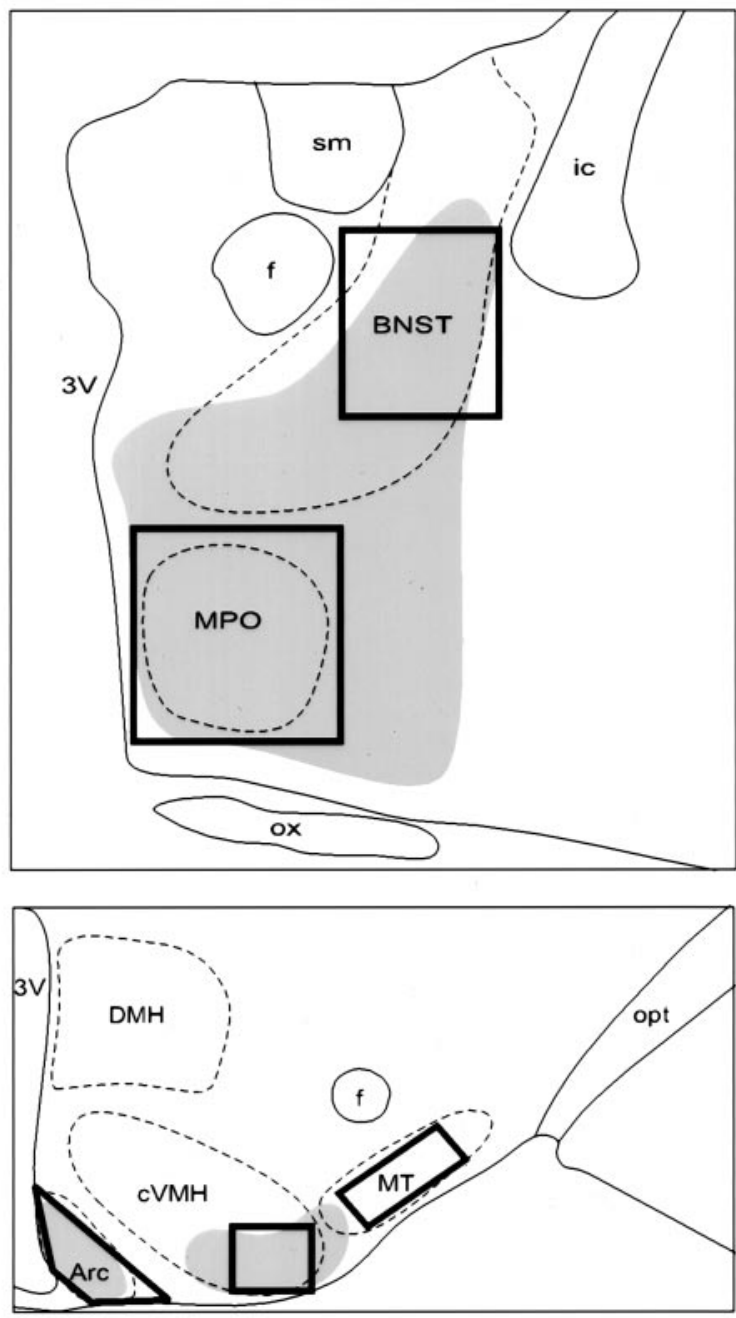

Figure 1. Drawings illustrating the regions of the brain examined for PR-immunoreactivity. Although the shaded regions indicate where the majority of PR-IR cells are located, PR-IR cells are not restricted to these regions. The regions outlined by thick black lines are the regions in which PR-IR cells were counted. $3 V$, Third ventricle; $A r c$, arcuate nucleus; $B N S T$, bed nucleus of the stria terminalis; $c V M H$, caudal ventromedial hypothalamus; $D M H$, dorsomedial hypothalamus; $f$, fornix; $i c$, internal capsule; $L S V$, ventrolateral septum; $L V$, lateral ventricle; $M e P D$, posterodorsal medial amygdala; $M P O$, medial preoptic nucleus; $M T$, medial tuberal nucleus; opt, optic tract; $o x$, optic chiasm; $r V M H$, rostral ventromedial hypothalamus; sm, stria medullaris.

particular, we focused on the induction of PRs in the $\mathrm{VMH}$, an area of the brain that is crucial for mediating the effects of estradiol and progesterone on sexual receptivity and which had not previously been examined for responsiveness to estradiol in ER $\alpha$-disrupted mice.

\section{MATERIALS AND METHODS}

\section{Experiment 1: immunocytochemical detection of PRs}

Animals. Animals were produced by heterozygotic breeding pairs. Each member of the pair had one normal and one disrupted ER $\alpha$ gene. All offspring were screened by PCR amplification of tail DNA (Lubahn et al., 1993). The breeding colony is maintained at the University of Virginia and was founded using mice provided by Dennis Lubahn (University of Missouri), which were heterozygotic for disruption of the ER $\alpha$ gene. Twenty adult ovariectomized mice, eight of which were ER $\alpha$-disrupted and 12 of which were WT littermates, were used in the immunocytochemistry experiment. One month after all the animals were ovariectomized, four of the ER $\alpha$-disrupted and eight wild-type mice were implanted subcutaneously with SILASTIC (Dow Corning, Midland, MI) capsules $[1.98 \mathrm{~mm}$ inner diameter (i.d.) $\times 3.17 \mathrm{~mm}$ outer diameter (o.d.)] containing $50 \mu \mathrm{g}$ of estradiol dissolved in $25 \mu \mathrm{l}$ of sesame oil; the remaining animals (four ER $\alpha$-disrupted and four WT mice) were im- planted with empty capsules. Five days after the capsules were implanted, the mice were perfused with $2 \%$ acrolein in a $0.1 \mathrm{M}$ phosphate buffer, and the brains were removed and immersed overnight in a $0.1 \mathrm{M}$ phosphate buffer containing $20 \%$ sucrose. Serial coronal sections (30 $\mu \mathrm{m})$ were made through the forebrain. The sections were collected into cryoprotectant (Watson et al., 1986) and then stored at $-20^{\circ} \mathrm{C}$ until every fourth section was processed for the immunocytochemical detection of either PRs or $\mathrm{ER} \alpha$.

Immunocytochemistry. The sections were removed from cryoprotectant and rinsed three times in $0.5 \mathrm{~m}$ Tris-buffered saline (TBS), $\mathrm{pH}$ 7.6. These rinses were followed by a 10 min incubation in a $1 \%$ sodium borohydride solution made in TBS. After rinsing again, the tissue was incubated for $20 \mathrm{~min}$ in TBS containing $20 \%$ normal goat serum, $1 \%$ bovine serum albumin, and $0.1 \%$ hydrogen peroxide. The sections were then transferred directly into a primary incubation buffer containing $1 \%$ gelatin, $0.02 \%$ sodium azide, $1 \%$ normal goat serum, and $0.5 \%$ Triton X-100 in TBS, pH 7.6, at $4^{\circ} \mathrm{C}$. Added to this buffer was either an antibody directed against the hinge region of the PR (H-928, $0.2 \mu \mathrm{g} / \mathrm{ml}$; StressGen Biotechnologies Corp., Victoria, British Columbia, Canada) or an antibody directed against the last 14 amino acids of the rat $\operatorname{ER} \alpha(\mathrm{C} 1355,1: 5000)$ (Friend et al., 1997). The last 14 amino acids of $\mathrm{ER} \alpha$ has no homology to the last 14 amino acids of $\mathrm{ER} \beta$, so C1355-immunoreactivity should reflect the presence of only ER $\alpha$. The specificity of the PR antibody H928 for the immunocytochemical detection of PR-immunoreactivity has been 

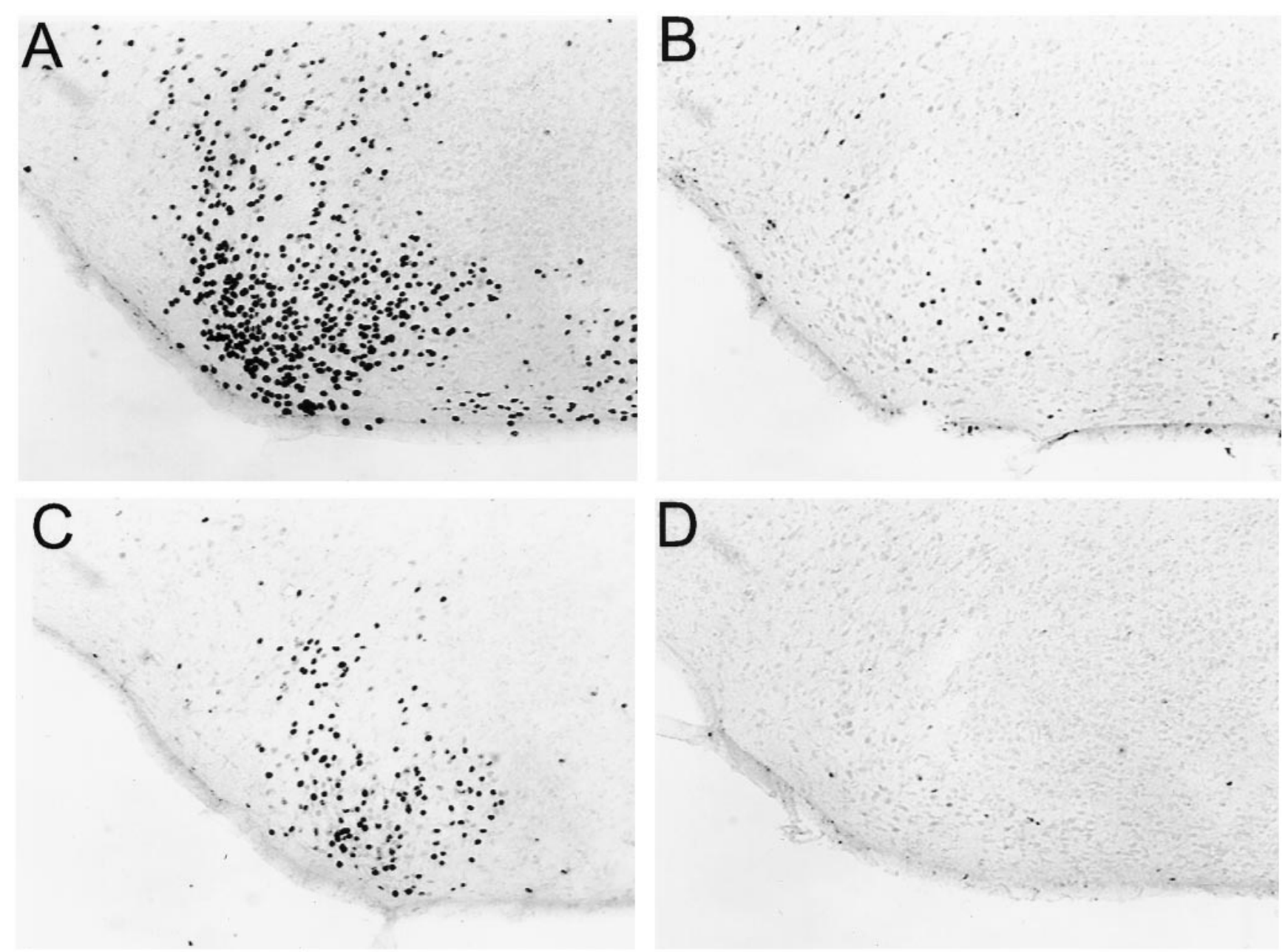

Figure 2. Representative photomicrograph (20× magnification) of PR-IR cells in the cVMH of an estradiol-treated WT mouse $(A)$, an oil-treated WT mouse $(B)$, an estradiol-treated $\mathrm{ER} \alpha$-disrupted mouse $(C)$, and an oil-treated ER $\alpha$-disrupted mouse $(D)$.

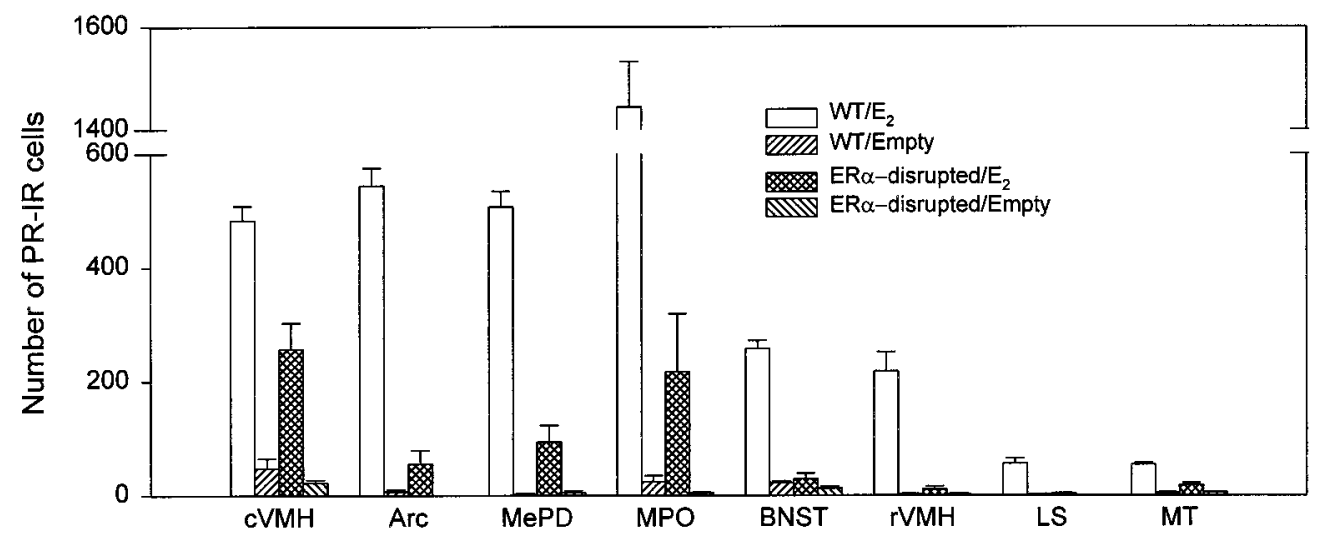

Figure 3. The number of PR-IR cells (+SEM) counted in WT and ER $\alpha$-disrupted mice after being implanted with either an estradiol-filled capsule or empty capsule for $5 \mathrm{~d}$. See Figure 1 for nomenclature.

established previously in rats (Auger et al., 1996). Using females that were heterozygous with respect to the disruption of the $\mathrm{ER} \alpha$ gene, the specificity of the C1355 ER $\alpha$ antibody was assessed by preadsorbing it for $24 \mathrm{hr}$ at $4^{\circ} \mathrm{C}$, with a $10 \mathrm{M}$ excess of the peptide against which it was generated and by omitting $\mathrm{C} 1355$ from the primary incubation buffer. The tissue was incubated with the appropriate primary antibody for $\sim 72$ $\mathrm{hr}$ at $4^{\circ} \mathrm{C}$. After this incubation, the tissue was rinsed three times in TBS,
$\mathrm{pH} 7.6$, at $23^{\circ} \mathrm{C}$ and incubated for $90 \mathrm{~min}$ in TBS containing $1.5 \%$ normal goat serum, $1.5 \%$ Triton $\mathrm{X}-100$, and $3 \mu \mathrm{g} / \mathrm{ml}$ either biotinylated goat anti-mouse IgG (Jackson ImmunoResearch, West Grove, PA) to label H928-immunoreactivity or biotinylated goat anti-rabbit $\mathrm{IgG}$ to label C1355-immunoreactivity. The sections were rinsed again and incubated for $90 \mathrm{~min}$ in TBS containing 1\% Avidin DH-biotinylated horseradish peroxidase H complex (Vectastain Elite; Vector Laboratories, Burlin- 

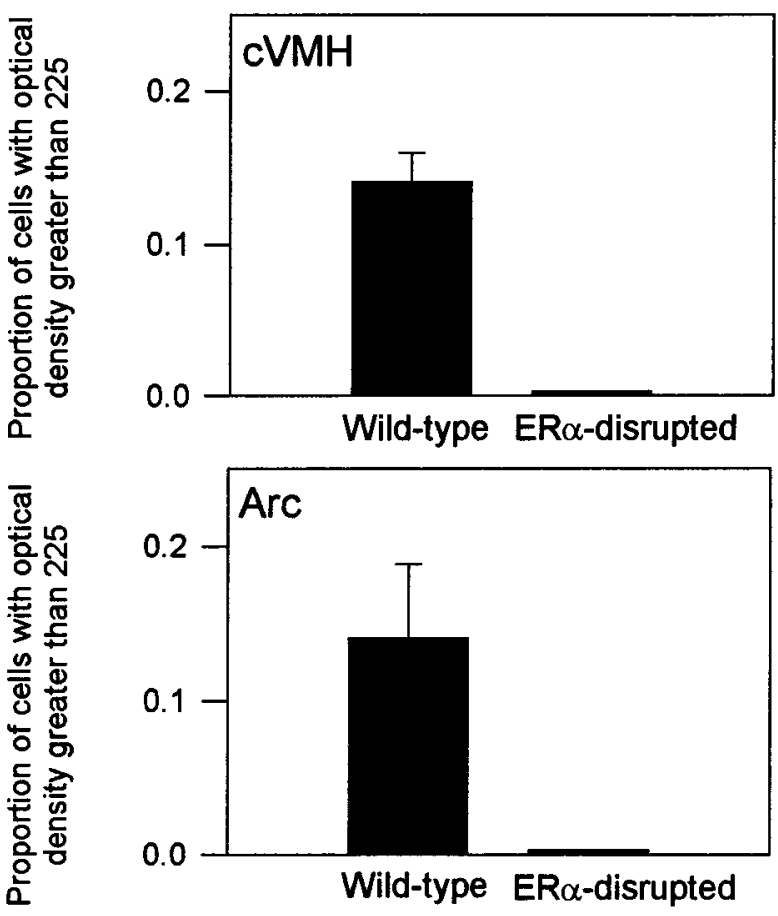

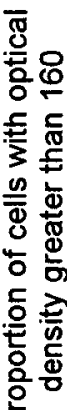

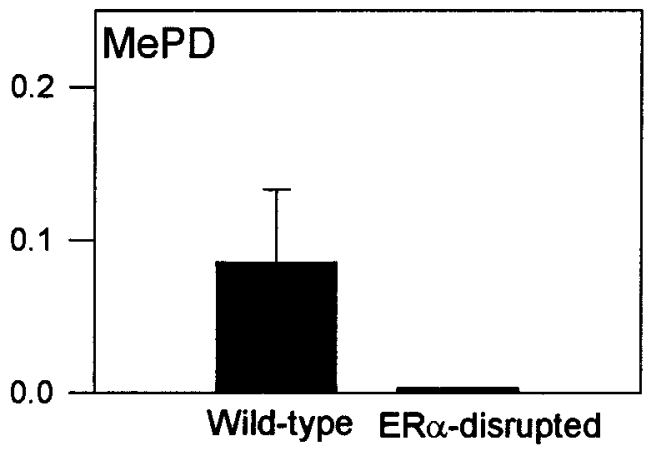

Figure 4. The proportion (+SEM) of darkly immunostained PR-IR cells counted in WT and ER $\alpha$-disrupted mice after being implanted with either an estradiol (E2)-filled or empty capsule for $5 \mathrm{~d}$. See Figure 1 for nomenclature.

game, CA). After three more rinses in TBS, the tissue was incubated for $\sim 5 \mathrm{~min}$ in TBS containing $0.05 \%$ diaminobenzidine and $0.05 \% \mathrm{H}_{2} \mathrm{O}_{2}$, rinsed again, mounted on gelatin-covered slides, and coverslipped with Permount (Fisher Scientific, Fair Lawn, NJ) before analysis of PR-immunoreactivity.

Image analysis. Computer-assisted analysis of PR-immunoreactivity was performed using a Leitz Dialux 20 microscope (Leitz, Wetzler, Germany), fitted with an MTI CCD72 camera (Dage MTI, Michigan City, MI) and connected to a Macintosh Quadra 700 computer using the public domain image analysis program developed by National Institutes of Health, Image 1.55 (available at http://rsb.info.nih.gov/nih-image/).

Briefly, the microscope was adjusted for Kohler illumination and focused on a black circle that had been affixed to a coverslipped slide. The camera gain and black levels were adjusted so that the blank portions of the slide produced gray levels of approximately five units, whereas the black circle produced gray levels of 254 units. Cells were considered to be PR-immunoreactive (PR-IR) if they satisfied two criteria. The putative PR-IR cells had to be $>10$ pixels but $<200$ pixels in area, and the optical density of the pixels corresponding to putative PR-IR cells had to exceed the average optical density of the surrounding tissue by a predetermined number of SDs. The number of SDs varied according to the area that was analyzed, because the difference in optical density between PR-IR cells and the surrounding tissue varied between areas. For a specific area, however, the same criterion was used for every section analyzed. The
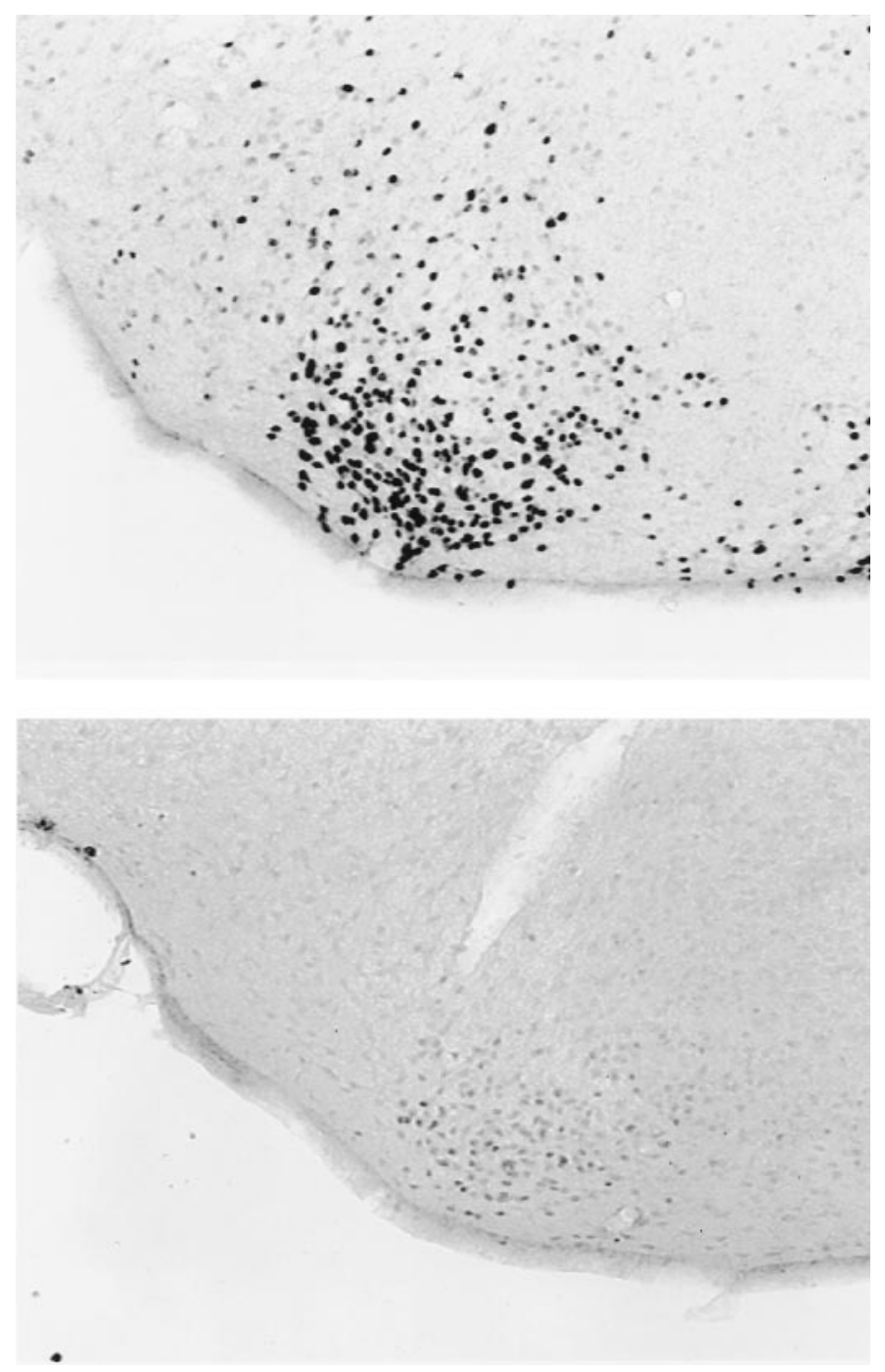

Figure 5. Representative photomicrograph (20× magnification) of $\mathrm{ER} \alpha$-IR cells in the cVMH of a WT mouse (top) and an estradiol-treated $\mathrm{ER} \alpha$-disrupted mouse (bottom).

areas analyzed in the forebrain are depicted in Figure 1 and were chosen because they were known to contain large numbers of estradiol-induced PRs in WT mice.

\section{Experiment 2: detection of estrogen receptor- $\beta$ and $E R \alpha$ $m R N A$ in the VMH using PCR}

Animals. Brains from four ovariectomized $\mathrm{ER} \alpha$-disrupted females and four ovariectomized WT females were used for the detection of $\mathrm{ER} \alpha$ and estrogen receptor- $\beta$ (ER $\beta)$ mRNA. Two animals of each genotype were implanted with steroid (5 $\mathrm{mm}$ of a 1:1 mixture of estradiol/cholesterol) in a SILASTIC capsule $(1.02 \mathrm{~mm}$ i.d. $\times 2.16 \mathrm{~mm}$ o.d. $)$. Five days after implants were received, all females were killed by an overdose injection of anesthesia. Brains were quickly removed and frozen on dry ice. Frozen tissue was sectioned in a cryostat. Four sections, $180 \mu \mathrm{m}$ each, were collected through the rostral to caudal VMH. A $26 \mathrm{gm}$ stylus was used to punch the frozen tissue, which was collected in a microf uge tube on dry ice.

$P C R$. Total RNA was purified from the $\mathrm{VMH}$ punches using an established procedure (Friend et al., 1997). To perform reverse transcription (RT)-PCR amplifications, a single RT-reaction was performed, and the resultant cDNA product was partitioned into four PCR reactions to amplify products for $\beta$-actin (equivalent of $0.5 \mu \mathrm{g}$ of RNA) or (equivalent of $1 \mu \mathrm{g}$ of RNA each) the $5^{\prime}$ end of mouse ER $\beta$ (exons 1-3), the 5' end of mouse ER $\alpha$ (exons 1-3), or the $3^{\prime}$ end of mouse ER $\alpha$ (exons 4-7). RT-PCR reactions were performed as described previously, except that only one set of amplifications $\left(35\right.$ cycles of $95^{\circ} \mathrm{C}$ for $1 \mathrm{~min}$, annealing 


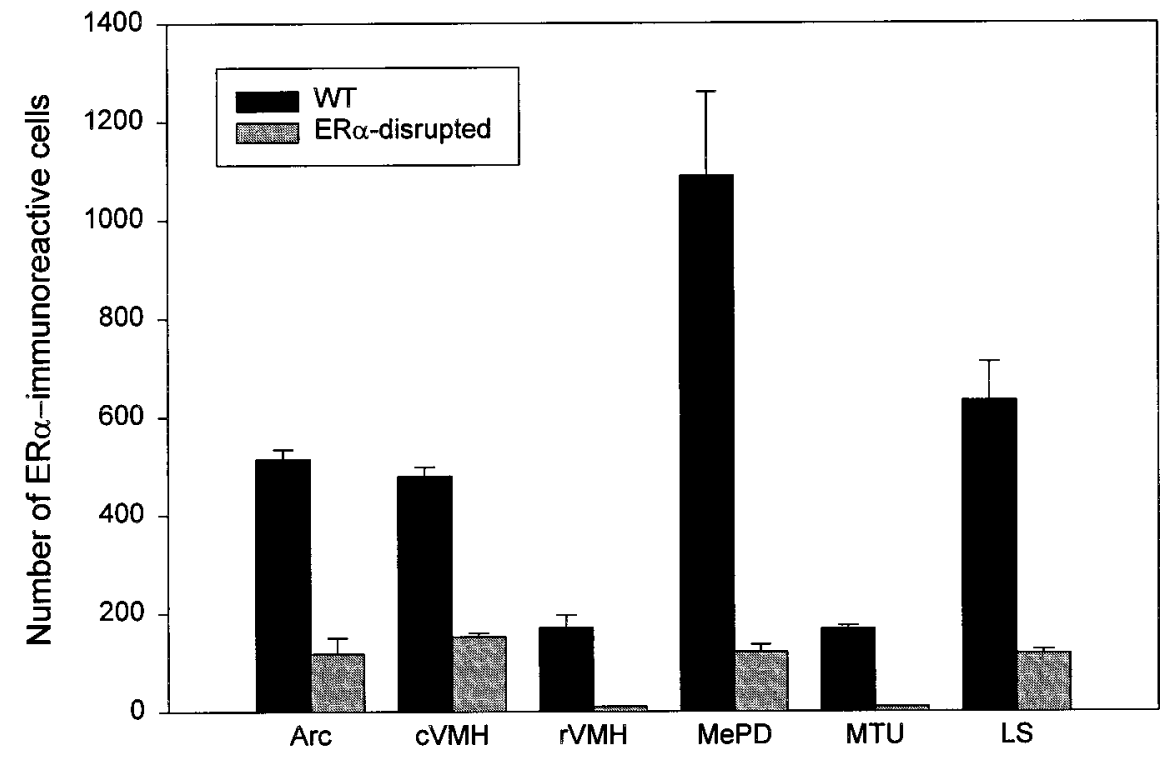

Figure 6. The number of ER $\alpha$-IR cells (+SEM) counted in WT mice (black bars) and $\mathrm{ER} \alpha$-disrupted mice ( gray bars). See Figure 1 for nomenclature.

temperature for $1 \mathrm{~min}, 72^{\circ} \mathrm{C}$ for $1 \mathrm{~min}$ ) was performed for the PCR amplification. The annealing reactions for mouse $\operatorname{ER} \beta$ were performed at $49^{\circ} \mathrm{C}$, but all other annealing reactions were performed at $55^{\circ} \mathrm{C}$. The primers used to amplify the mouse $\mathrm{ER} \beta$ product ( $351 \mathrm{bp}$ ) were ERBST: 5'-CTATGACATTCTACAGTCC-3' and ERB3: 5'-GTAATGATACCCAGAGCA- $3^{\prime}$. Primers for the $5^{\prime}$ end of ER $\alpha$ (638 bp for intact $\mathrm{ER} \alpha$ ) were RERC: 5'-GACCATGACCATGACCCT-3' and MER4: 5'CTTGCAGCCTTCACAGGAC- $3^{\prime}$. Primers to amplify the $3^{\prime}$ end of the coding region of $\mathrm{ER} \alpha$ (441 bp) were SERRB: 5'-GATCCTTCTAGACCCTTC-3' and MER7: 5'-CTTGTCCAGGACTCGGTGGAT-3'. After amplification, products were displayed on a $1 \%$ agarose gel containing ethidium bromide as described previously (Friend et al., 1997).

Statistics. The effects of genotype and hormone treatment on PR-IR cell numbers were assessed using an ANOVA procedure (Systat Version 6.1). When the analysis indicated that there was a significant interaction between treatment effects, post hoc comparisons were made between group means using the Newman-Keuls procedure. It was decided a priori to compare the number of PR-IR cells in oil-treated and estradioltreated ER $\alpha$-disrupted mice in each of the areas of the brain that were examined. These comparisons were made using $t$ tests or nonparametric tests where appropriate.

\section{RESULTS}

\section{Experiment 1}

The ability of estradiol to induce PRs in this experiment was strongly influenced by the genotype of the animals (Figs. 2, 3). That is, although treatment with estradiol significantly increased PR-IR cell number in each of the areas examined $(p<0.05$ in all cases), post hoc comparisons revealed that WT animals treated with estradiol had significantly more PR-IR cells than estradioltreated $\mathrm{ER} \alpha$-disrupted animals ( $p<0.05$ in all cases). Nevertheless, estradiol-treated ER $\alpha$-disrupted mice did have more PR-IR cells than oil-treated $\mathrm{ER} \alpha$-disrupted mice in the caudal VMH (cVMH), arcuate nucleus (Arc), and posterodorsal medial amygdala $(\mathrm{MePD})(p<0.05$ in all cases $)$. There was also a large difference between the two groups in the medial preoptic nucleus (MPO), but the difference did not reach statistical significance $(p>0.05)$. No differences were observed between oil-treated WT and oil-treated ER $\alpha$-disrupted mice with respect to PR-IR cell number $(p>0.05)$.

In addition to quantifying PR-IR cell numbers, we determined whether there were differences in the proportion of darkly immunostained cells found in the MePD, Arc, and cVMH of estradioltreated WT and ER $\alpha$-disrupted mice (Fig. 4). Contrasting the proportion of darkly immunostained cells (cells with optical densities $>225$ units) in each group in the Arc and cVMH, we found that estradiol-treated WT mice had a greater proportion of darkly immunostained cells than did ER $\alpha$-disrupted mice $(p<0.05$ in all cases). Because there were few cells in the MePD that had optical densities $>225$ units, the threshold was adjusted, and contrasts in this area were made between cells having optical densities $>160$ units. Again, estradiol-treated WT mice had a significantly greater proportion of darkly immunostained cells than estradiol-treated ER $\alpha$-disrupted mice $(p<0.05)$.

Although ER $\alpha$-disrupted mice had fewer ER $\alpha$-IR cells than WT mice ( $p<0.05$ in all cases), $\mathrm{ER} \alpha$-IR cells were observed in the Arc, cVMH, MePD, and ventrolateral septum of both groups (Figs. 5, 6). In contrast, ER $\alpha$-IR cells were not seen in the rostral $\mathrm{VMH}$ and medial tuberal nucleus of the ER $\alpha$-disrupted mice. Although $\mathrm{ER} \alpha$-IR cells were also detected in the MPO (189 cells) and bed nucleus of the stria terminalis (BNST) (23 cells) of $\mathrm{ER} \alpha$-disrupted mice, insufficient numbers of well matched sections were available for contrasts with WT animals. Preadsorption of the $\mathrm{C} 1355$ antibody with the peptide against which it was raised and omission of the C1355 antibody from the incubation buffer eliminated all $\mathrm{ER} \alpha$ immunostaining (Fig. 7).

\section{Experiment 2}

All mRNA samples taken from the VMH showed PCR products for actin mRNA, $\mathrm{ER} \beta$ mRNA, and the $3^{\prime}$ end of $\mathrm{ER} \alpha$ mRNA. Only the WT females showed an appropriately sized exon 1-3 PCR product corresponding to the 5' end of the full-length ER $\alpha$ mRNA (Fig. 8). The estradiol-treated animals had more than one band corresponding to PCR products for the ER $\beta$ mRNA. These latter $\mathrm{ER} \beta$ PCR products have not been characterized, but they are similar in size to products that would lack exon 2. Such products have been characterized in human pituitary tumors (M. Shupnik, unpublished data), but the protein product of such mRNAs would only correspond to exon 1 and are unlikely to be bioactive.

\section{DISCUSSION}

Disruption of the ER $\alpha$ gene suppressed, but did not completely inhibit, the induction of progestin receptors in $\mathrm{ER} \alpha$-disrupted 

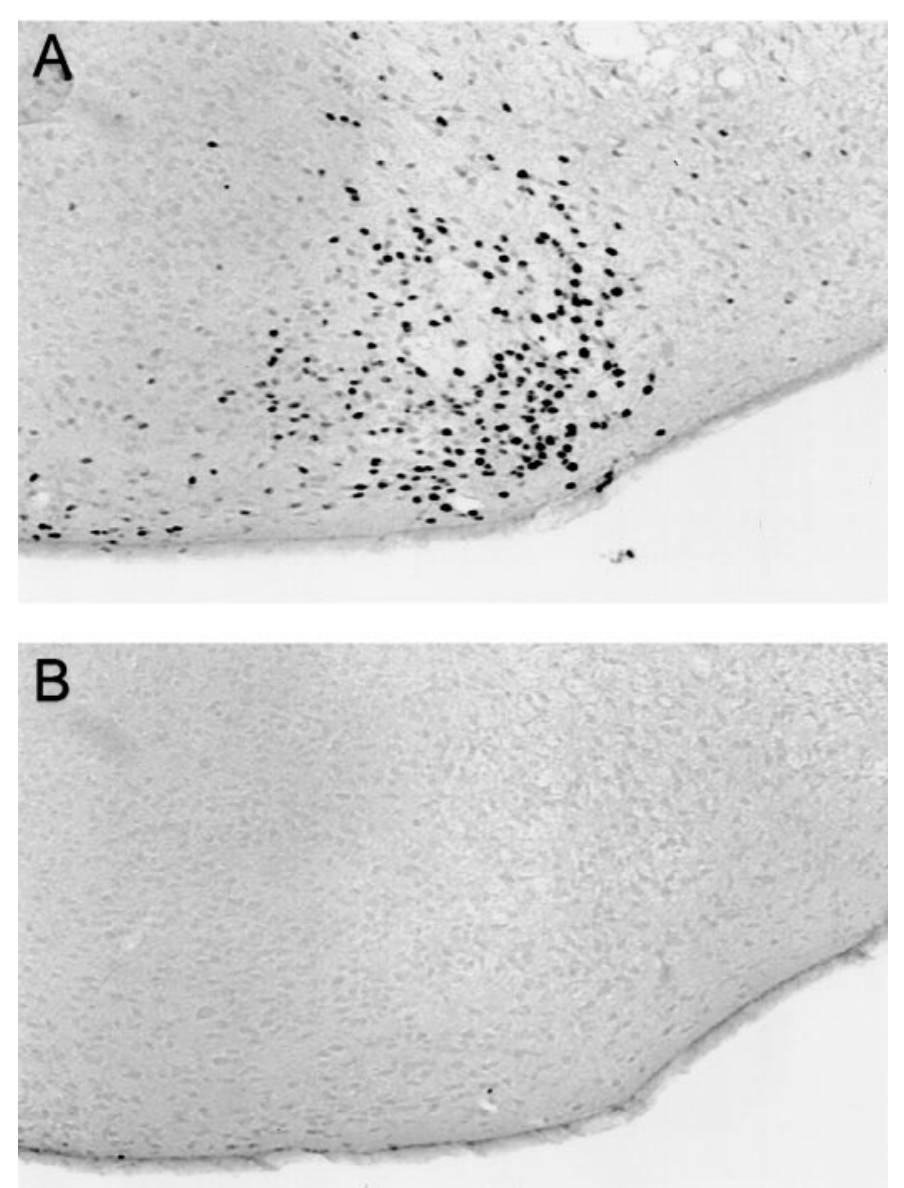

\section{C}

Figure 7. Representative photomicrographs (20× magnification) of the cVMH showing ER $\alpha$ immunostaining produced by $\mathrm{C} 1355(A)$, immunostaining when $\mathrm{C} 1355$ was preadsorbed with the peptide against which it was raised $(B)$, and immunostaining in the absence of $\mathrm{C} 1355(C)$.

mice. More specifically, although $\mathrm{ER} \alpha$-disrupted mice had fewer estradiol-induced progestin receptors than WT mice, treatment with estradiol increased PR-IR cell number in the MePD, Arc, and $\mathrm{cVMH}$ of ER $\alpha$-disrupted mice. When the intensity of the PR immunostaining was analyzed, it was found that the proportion of cells that were darkly immunostained in ER $\alpha$-disrupted mice was smaller than the proportion that was darkly immunostained in WT mice. Differences in the optical density or intensity of im- munostaining can be attributed to differences that exist between cells in the relative amount or concentration of antigen they contain (Auger and Blaustein, 1995). With this in mind, one interpretation of our results is that, although estradiol caused an increase in PR-IR cell number in $\mathrm{ER} \alpha$-disrupted mice, the relative number of PRs induced in these cells was smaller in $\operatorname{ER} \alpha$ disrupted mice than in WT mice. The apparent difference in PR concentration between WT and ER $\alpha$-disrupted mice is consistent with the results of the in situ hybridizations performed by Shughrue and colleagues (1997b) and suggests that PR synthesis in $\mathrm{ER} \alpha$-disrupted mice is impaired even in those cells that exhibit estradiol-induced PR-immunoreactivity.

The pattern of estradiol-induced PR expression we observed in $\mathrm{ER} \alpha$-disrupted mice is very similar to the pattern of estradiolinduced PR mRNA described in a previous report for sites that both studies examined (Shughrue et al., 1997b). In the previous study, PR mRNA levels were found to increase in the BNST and preoptic area (POA) of ER $\alpha$-disrupted mice after treatment with estradiol, but changes in more caudal regions of the forebrain, areas such as the MePD, Arc, and cVMH, were not examined in that study. Responsiveness to estradiol in ER $\alpha$-disrupted mice is not limited only to the brain; it is also evident in other systems and tissues. For instance, estradiol is equally effective in $\operatorname{ER} \alpha$ disrupted mice and WT mice at inhibiting the thickening of arterial walls after arterial injury (Iafrati et al., 1997). What remains to be identified is the mechanism that mediates this responsiveness to estradiol in $\mathrm{ER} \alpha$-disrupted mice.

One possibility is that the induction of progestin receptors in $\mathrm{ER} \alpha$-disrupted mice is mediated via an estrogen receptor that is distinct from $\mathrm{ER} \alpha$. $\mathrm{ER} \beta$, for instance, is a novel estrogen receptor that was initially identified in rat tissue and then subsequently found to exist in mice and humans (Kuiper et al., 1996, 1997; Mosselman et al., 1996; Tremblay et al., 1997). Analysis of the ligand-binding properties of $\operatorname{ER} \alpha$ and $\operatorname{ER} \beta$ has shown that the two receptors bind estradiol with equal affinity (Kuiper et al., 1997). In addition, the DNA-binding domains of $\operatorname{ER} \beta$ and $\operatorname{ER} \alpha$ are quite similar to one another, having a homology of $97 \%$ (Tremblay et al., 1997). Although it has not been determined whether $\operatorname{ER} \beta$ regulates PR synthesis, the homology that exists in the DNA-binding domains of $\operatorname{ER} \alpha$ and $\operatorname{ER} \beta$ is consistent with this possibility. $\mathrm{ER} \alpha$ regulates expression of the PR gene via its interactions with estrogen response elements (EREs) within the 5 '-flanking region of the PR gene (Kraus et al., 1994). Given that $\operatorname{ER} \beta$ binds to these EREs, then it might be possible for $\operatorname{ER} \beta$ to regulate the expression of PR (Paech et al., 1997). Consistent with this hypothesis is the observation that $\operatorname{ER} \beta$ mRNA and protein are present in many PR-containing forebrain regions of female rats and ER $\alpha$-disrupted mice (Shughrue et al., 1996, 1998; Li et al., 1997).

The hypothesis that $\operatorname{ER} \beta$ mediated the induction of PRs by estradiol in ER $\alpha$-disrupted mice is consistent with our observation that a PCR product corresponding to $\mathrm{ER} \beta$ mRNA is present in the VMH of ER $\alpha$-disrupted mice. Previous reports of the distribution of $\operatorname{ER} \beta$ in the hypothalamus have, however, described ER $\beta$ as absent in VMH of rats (Shughrue et al., 1996, 1997a) and "sparse or absent" in the VMH of ER $\alpha$-disrupted mice (Shughrue et al., 1998). The discrepancy between the results of the present study and those of previous studies may be attributed to methodological differences between the studies. Shughrue and colleagues (1996, 1997a, b, 1998) used in situ hybridization to map the distribution of $\operatorname{ER} \beta$ mRNA in the brains of rats and ER $\alpha$-disrupted mice, whereas PCR (using primers having differ- 
Figure 8. PCR products representing ER mRNA in tissue of WT and ER $\alpha$-disrupted female mice. $A$ shows $5^{\prime}$ $\mathrm{ER} \alpha$ product, $B$ shows $3^{\prime} \mathrm{ER} \alpha$ product, $C$ depicts actin present in all samples, and $D$ shows ER $\beta$ product. Control lanes run without PCR product are designated as $C$. Marker 1 (M1) (a ligation ladder of progressive lengths of 123 bp DNA) was used for gels $A, B$, and $D$. In gel $C$, the marker used (M2) is DNA from bacteriophage $\lambda$ digested with Bstel restriction endonuclease. In $D$, the first lane contains marker DNA, and the last lane is the negative control.

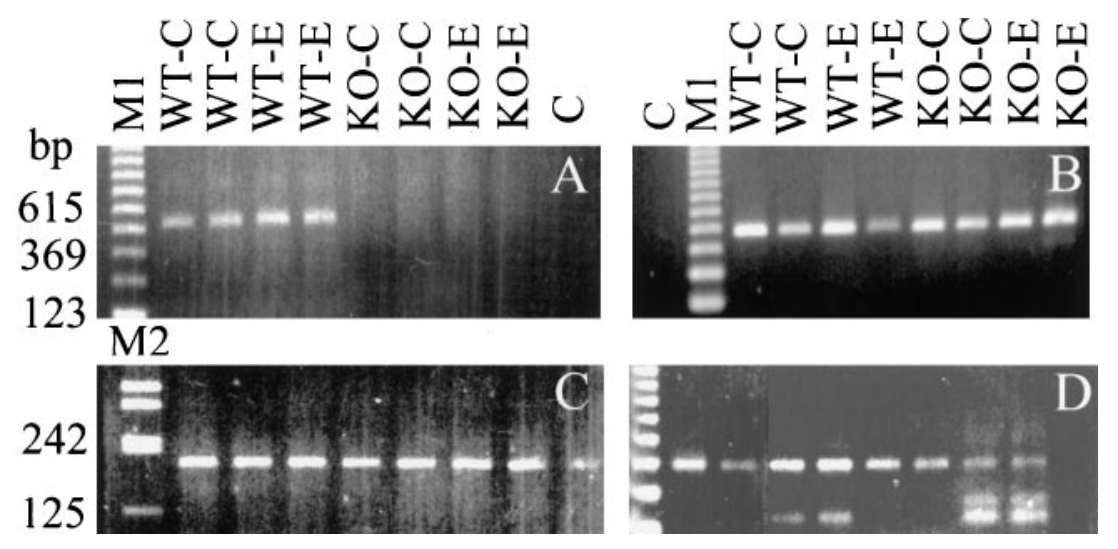

ent sequences than the probes used by Shughrue and colleagues) was used in the present study. In situ hybridization, although providing excellent neuroanatomical localization of $\operatorname{ER} \beta$ mRNA, may not be as sensitive as PCR in detecting mRNA that occurs in low abundance. Despite the detection of PCR products corresponding to $\mathrm{ER} \beta$ mRNA in the $\mathrm{VMH}$, it is still very important to determine whether $\mathrm{ER} \beta$ protein is present in the $\mathrm{VMH}$ and whether $\operatorname{ER} \beta$ has the capacity to mediate the effects of estradiol on PR synthesis. Until such time as the role of $\mathrm{ER} \beta$ in PR regulation is determined, alternative hypotheses must be considered.

An alternative mechanism that might contribute to the induction of PR-immunoreactivity in $\mathrm{ER} \alpha$-disrupted mice is the activation of mutant $\mathrm{ER} \alpha$ or $\mathrm{ER} \alpha$ splice variants by estradiol. The $\mathrm{ER} \alpha$ gene in $\mathrm{ER} \alpha$-disrupted mice was disrupted by inserting the Neo gene into exon 2 of the gene encoding $\mathrm{ER} \alpha$, the portion of the gene that encodes the $\mathrm{N}$-terminal region of $\mathrm{ER} \alpha$ protein. This insertion disrupts the reading frame of the ER $\alpha$ gene and introduces multiple stop codons (Lubahn et al., 1993). Consequently, the tissues of $\operatorname{ER} \alpha$-disrupted mice contain no full-length $\operatorname{ER} \alpha$ mRNA. However, despite this disruption of the $\operatorname{ER} \alpha$ gene, portions of it are transcribed. The detection of PCR products in the $\mathrm{VMH}$ of ER $\alpha$-disrupted mice that correspond to the $3^{\prime}$ end of $\mathrm{ER} \alpha$ mRNA not only confirms a previous report describing the presence of this portion of $\mathrm{ER} \alpha$ mRNA in the hypothalamus of ER $\alpha$-disrupted mice (Couse et al., 1997) but also bolsters the hypothesis that an $\mathrm{ER} \alpha$ splice variant could mediate the effects of estradiol in the VMH. The results of our PCR analysis also validate previous and current reports of $\mathrm{ER} \alpha$-IR in the VMH of ER $\alpha$-disrupted mice. In a previous study, $\mathrm{H} 222$, an antibody that recognizes the ligand-binding region of $\operatorname{ER} \alpha$, was used to detect ER $\alpha$-IR (Rissman et al., 1997). Using an antibody, ER21, which recognizes the $\mathrm{N}$-terminal region of $\mathrm{ER} \alpha$, Ogawa and colleagues (1997) failed to detect ER $\alpha$-IR in the VMH of ER $\alpha$-disrupted mice; however, in the same study, they did report sparse or residual $\mathrm{ER} \alpha$-IR in the medial POA. The lack of $\operatorname{ER} \alpha$-IR detected in the VMH using the ER21 antibody is consistent with the results of the PCR analysis undertaken in the present study.

Couse and colleagues (1995) have assessed the biological activity of two $\mathrm{ER} \alpha$ splice variants detected in the uterus of $\mathrm{ER} \alpha$ disrupted mice. The smaller of the two splice variants they detected, ER2, would produce a protein that probably binds neither DNA nor estradiol, whereas the larger splice variant, ER1, is capable of coding a protein that binds estradiol. ER1 is transcriptionally active in vitro, but despite its presence in the uterus, the uterus of $\mathrm{ER} \alpha$-disrupted mice is not responsive to estradiol (Couse et al., 1995). This does not mean, however, that a splice- variant such as ER1 could not mediate the responsiveness of hypothalamic cells to estradiol. Rather, the induction of PRs in the hypothalamus may be a more sensitive indicator of transcriptional activity of ER1 in vivo than is uterine responsiveness. This hypothesis is consistent with the results of a number of studies showing cell-specific differences, even among cells that contain estrogen receptors, in the ability of estradiol to induce changes in the translation of proteins and transcription mRNAs (i.e., Shupnik et al., 1989; Ing and Tornesi, 1997). Whether or not the PCR products corresponding to the $3^{\prime} \mathrm{ER} \alpha$ mRNA detected in the present study corresponds to the ER1 transcript detected by Couse and colleagues (1995) remains to be determined. However, the presence of an $\mathrm{ER} \alpha$ splice variant in the $\mathrm{VMH}$ of $\mathrm{ER} \alpha$ disrupted mice raises the possibility that an $\operatorname{ER} \alpha$ splice variant mediates the induction of PRs by estradiol.

Alternatively, as yet unidentified nongenomic estradiolsensitive mechanisms could mediate the responses of $\operatorname{ER} \alpha$ disrupted mice to estradiol. Among the candidate mechanisms are membrane-bound estrogen receptors (Ramirez et al., 1996). The function of this type of receptor has yet to be well characterized in the brain, but it has been suggested that membranebound receptors that bind steroid hormones may influence neuroendocrine function (DeBold and Frye, 1994; Frye et al., 1996). As well, the possibility must be considered that other estrogen receptors, estrogen receptors distinct from $\operatorname{ER} \alpha$ and $\operatorname{ER} \beta$, may mediate the effects of estradiol in the CNS.

In summary, it is clear that $\mathrm{ER} \alpha$-disrupted mice retain a residual responsiveness to estradiol. This responsiveness is sufficient to regulate PR-immunoreactivity but is insufficient to induce sexual behaviors under the conditions tested (Rissman et al., 1997). One interpretation of this pattern of responsiveness is that $\mathrm{ER} \alpha$ splice variants act in conjunction with other mechanisms, possibly $\operatorname{ER} \beta$, to induce progestin receptors and regulate sexual behaviors. Although this is an exciting hypothesis, we cannot yet discard the possibility that it is an $\mathrm{ER} \alpha$ splice variant or an alternate mechanism that mediates the responses of $\mathrm{ER} \alpha$ disrupted mice to estradiol.

\section{REFERENCES}

Auger AP, Blaustein JD (1995) Progesterone enhances an estradiolinduced increase in Fos immunoreactivity in localized regions of female rat forebrain. J Neurosci 15:2272-2279.

Auger AP, Moffatt CA, Blaustein JD (1996) Reproductively-relevant stimuli induce Fos-immunoreactivity within progestin receptorcontaining neurons in localized regions of female rat forebrain. J Neuroendocrinol 8:831-838.

Bittencourt JC, Presse F, Arias C, Peto C, Vaughn J, Hahon J-L, Vale W, Sawchenko PE (1992) The melanin-concentrating hormone system of 
the rat brain: an immuno- and hybridization histochemical characterization. J Comp Neurol 319:218-245.

Blaustein JD, Feder HH (1979) Cytoplasmic progestin receptors in guinea pig brain: characteristics and relationship to the induction of sexual behavior. Brain Res 169:481-497.

Blaustein JD, Feder HH (1980) Nuclear progestin receptors in guinea pig brain measured by an in vitro exchange assay after hormonal treatments that affect lordosis. Endocrinology 106:1061-1069.

Blaustein JD, Olster DH (1989) Gonadal steroid hormone receptors and social behaviors. In: Advances in comparative and environmental physiology (Balthazart J, ed), pp 31-104. Berlin: Springer.

Boling JL, Blandau RJ (1939) The estrogen-progesterone induction of mating responses in the spayed female rat. Endocrinology 25:359-364.

Brown TJ, Blaustein JD (1984) inhibition of sexual behavior in female guinea pigs by a progestin receptor antagonist. Brain Res 301:343-349.

Couse JF, Curtis SW, Wahburn TF, Lindzey J, Golding TS, Lubahn DB, Smithies O, Korach KS (1995) Analysis of transcription and estrogen insensitivity in the female mouse after targeted disruption of the estrogen receptor gene. Mol Endocrinol 9:1441-1454.

Couse JF, Lindzey J, Gustafsson JA, Korach KS (1997) Tissue distribution and quantitative analysis of estrogen receptor- $\alpha(\mathrm{ER} \alpha)$ and estrogen receptor- $\beta(\mathrm{ER} \beta)$ messenger ribonucleic acid in the wild-type and ER $\alpha$-knockout mouse. Endocrinology 138:4613-4621.

DeBold JF, Frye CA (1994) Genomic and non-genomic actions of progesterone in the control of female hamster sexual behavior. Horm Behav 28:445-453.

Friend KE, Resnick EM, Ang LW, Shupnik MA (1997) Specific modulation of estrogen receptor mRNA isoforms in rat pituitary throughout the estrous cycle and in response to steroid hormones. Mol Cell Endocrinol 131:147-155.

Frye CA, Van Keuren KR, Rao PN, Erskine MS (1996) Progesterone and $3 \alpha$-androstanediol conjugated to bovine serum albumin affect estrous behavior when applied to the $\mathrm{MBH}$ and POA. Behav Neurosci 110:603-612.

Iafrati MD, Karas RH, Aronovitz M, Kim S, Sullivan TR, Lubahn DB, O’Donnell TF, Korach KS, Mendelsohn ME (1997) Estrogen inhibits the vascular injury response in estrogen receptor- $\alpha$ deficient mice. Nat Med 3:545-548.

Ing NH, Tornesi MB (1997) Estradiol up-regulates estrogen receptor gene expression in specific ovine uterine cells. Biol Reprod 56:12051215 .

Kalra SP (1993) Mandatory neuropeptide-steroid signaling for the preovulatory luteinizing hormone-releasing hormone discharge. Endocr Rev 14:507-538.

Kraus WL, Montano MM, Katzenellenbogen BS (1994) Identification of multiple, widely spaced estrogen-responsive regions in the rat progesterone receptor gene. Mol Endocrinol 8:952-969.

Kuiper GGJM, Enmark E, Pelto-Huikko M, Nilsson S, Gustafsson J-A (1996) Cloning of a novel estrogen receptor expressed in rat prostate and ovary. Proc Natl Acad Sci USA 93:5925-5930.

Kuiper GGJM, Carlson B, Grandien K, Enmark E, Haggblad J, Nilsson S, Gustafsson J-A (1997) Comparison of the ligand binding specificity and transcript tissue distribution of estrogen receptor $\alpha$ and $\beta$. Endocrinology 138:863-870.

Li X, Schwartz PE, Rissman EF (1997) Distribution of estrogen receptor $\beta$-like immunoreactivity in rat brain. Neuroendocrinology 66:63-67.

Lubahn DB, Moyer JS, Golding TS, Couse JF, Korach KS, Smithies O (1993) Alteration of reproductive function but not prenatal sexual development after insertional disruption of the mouse estrogen receptor gene. Proc Natl Acad Sci USA 90:11162-11166.

Lydon JP, DeMayo FJ, Funk CR, Mani SK, Hughs AR, Montgomery CA, Shyamala G, Conneely OM, O’Malley BW (1995) Mice lacking pro- gesterone receptor exhibit pleiotropic reproductive abnormalities. Genes Dev 9:2266-2278.

MacLusky NJ, McEwen BS (1978) Oestrogen modulates progestin receptor concentrations in some rat brain regions but not in others. Nature 274:276-278.

Mani SK, Blaustein JD, Allen JMC, Law S, O'Malley BW, Clark JH (1994) Inhibition of rat sexual behavior by antisense oligonucleotides to the progesterone receptor. Endocrinology 135:1409-1414.

Mosselman S, Polman J, Dijkema R (1996) ER $\beta$ : identification and characterization of a novel human estrogen receptor. FEBS Lett 392:49-53.

Ogawa S, Olazabal UE, Parhar I, Pfaff DW (1994) Effects of intrahypothalamic administration of antisense DNA for progesterone receptor mRNA on reproductive behavior and progesterone receptor immunoreactivity in female rat. J Neurosci 14:1766-1774.

Ogawa S, Taylor JA, Lubahn DB, Korach KS, Pfaff DW (1996) Reversal of sex roles in genetic female mice by disruption of the estrogen receptor gene. Neuroendocrinology 64:467-470.

Ogawa S, Lubahn DB, Korach K, Pfaff DW (1997) Behavioral effects of estrogen receptor gene disruption in male mice. Proc Natl Acad Sci USA 94:1476-1481.

Paech K, Webb P, Kuiper GGJM, Nilsson S, Gustafsson J-A, Kushner PJ, Scanlan TS (1997) Differential ligand activation of estrogen receptors $\mathrm{ER} \alpha$ and ER $\beta$ at AP1 sites. Science 277:1508-1510.

Pfaff DW, Schwartz-Giblin S, McCarthy MM, Kow L-M (1994) Cellular and molecular mechanisms of female reproductive behaviors. In: The physiology of reproduction (Knobil E, Neill JD, eds), pp 107-220. New York: Raven.

Ramirez VD, Zheng J, Siddique KM (1996) Membrane receptors for estrogen, progesterone, and testosterone in the rat brain: fantasy or reality. Cell Mol Neurobiol 16:175-197.

Rissman EF, Early AH, Taylor JA, Korach KS, Lubahn DB (1997) Estrogen receptors are essential for female sexual receptivity. Endocrinology 138:507-510.

Rubin BS, Barfield RJ (1983a) Induction of estrous behavior in ovariectomized rats by sequential replacement of estradiol and progesterone to the ventromedial hypothalamus. Neuroendocrinology 37:218-224.

Rubin BS, Barfield RJ (1983b) Progesterone in the ventromedial hypothalamus facilitates estrous behavior in ovariectomized, estrogenprimed rats. Endocrinology 113:797-804.

Shughrue PJ, Komm B, Merchenthaler I (1996) The distribution of estrogen receptor- $\beta$ mRNA in the rat hypothalamus. Steroids 61:678-681.

Shughrue PJ, Lane M, Merchenthaler I (1997a) The comparative distribution of estrogen receptor- $\alpha$ and $-\beta$ mRNA in the rat central nervous system. J Comp Neurol 338:1-19.

Shughrue PJ, Lubahn DB, Negro-Vilar A, Korach KS, Merchenthaler I (1997b) Responses in the brain of estrogen receptor- $\alpha$ disrupted mice. Proc Natl Acad Sci USA 94:11008-11012.

Shughrue PJ, Scrimo P, Lane M, Askew R, Merchenthaler I (1998) The distribution of estrogen receptor- $\beta$ mRNA in forebrain regions of the estrogen receptor knockout mouse. Endocrinology 138:5649-5652.

Shupnik MA, Gordon MS, Chin WW (1989) Tissue specific regulation of rat estrogen receptor mRNAs. Mol Endocrinol 3:660-665.

Tremblay GB, Tremblay A, Copeland NG, Gilbert DJ, Jenkins NA, Labrie F, Giguere V (1997) Cloning, chromosomal localization, and functional analysis of the murine estrogen receptor $\beta$. Mol Endocrinol 11:353-365.

Watson RE, Wiegand SJ, Clough RW, Hoffman GE (1986) Use of cryoprotectant to maintain long-term peptide immunoreactivity and tissue morphology. Peptides 7:155-159. 